\title{
More ways than one to slip on a banana: unusual forms of water sport injuries
}

\author{
Carl Clinton MB ChB FIMLS ATLS, DIP Sports Med \\ Jersey General Hospital
}

This paper reviews ten cases that presented to this Department, during a 2-week period in August 1991. The injuries were all caused by falling/slipping off a 'Banana', representing unusual forms of water sport injuries. A 'Banana' is the nickname given to an inflatable craft which is towed behind a speedboat. Its full name is a 'Bronco Fun-Rider' and it is a long, yellow, banana-shaped inflatable craft with straps for holding on to along its length. The idea is for people to sit behind one another astride the 'Banana' and remain seated during the ride while the speedboat tows the 'Banana' out to sea at a speed usually of 20-25 mph (the riders wear life-jackets).

The injuries were all different in nature. Age range was 10-47 (mean 25) years; sex ratio male:female was 4:6; three were local residents and seven holiday makers.

\section{Case reports}

\section{Case 1}

A 19-year-old woman presented with a tooth embedded in the occiput area of her scalp.

\section{Case 2}

A 20-year-old woman, friend of Case 1 and riding behind her, presented with bleeding upper gums and missing right upper incisor.

\section{Case 3}

A 42-year-old man presented with a 1.5 - $\mathrm{cm}$ laceration to the bridge of his nose.

\section{Case 4}

This patient, a 10-year-old girl, presented with a head injury. She had suffered no loss of consciousness but her scalp was tender to palpation with a slight

Address for correspondence: Dr Carl Clinton, Accident and Emergency Department, Jersey General Hospital, Jersey, Channel Islands

(C) 1992 Butterworth-Heinemann Ltd 0306-3674/92/030134-02

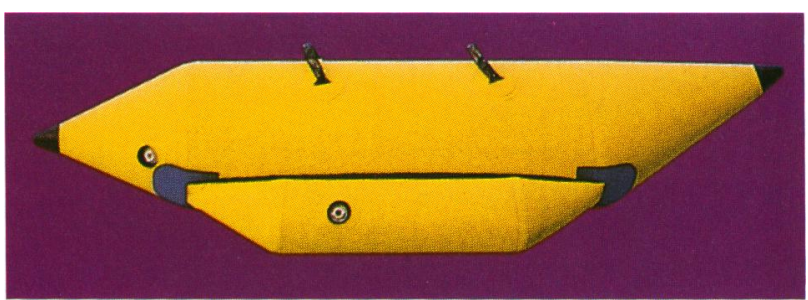

Figure 1. A three-man ride 'Banana'. Reproduced with the permission of Veteka Sports Ltd, Great Bookham, UK.

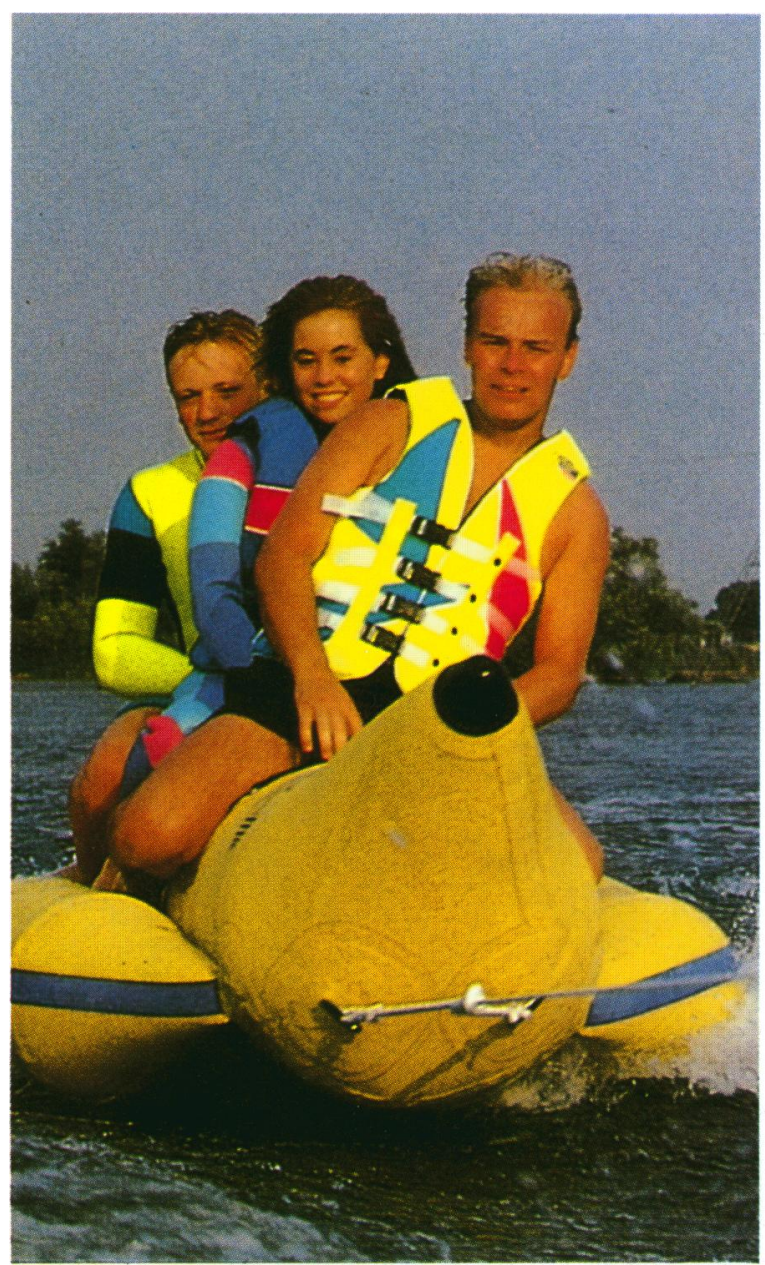

Figure 2. The 'Banana' in action. Reproduced with the permission of Veteka Sports Ltd, Great Bookham, UK. 
haematoma over her right forehead and the bridge of her nose.

\section{Case 5}

A 35-year old man presented with a 3-cm laceration to his occiput.

\section{Case 6}

This 47-year-old patient presented with a dislocated right shoulder; radiography confirmed an anterior dislocation.

\section{Case 7}

A 21-year-old woman presented with a large rightsided periorbital haematoma.

\section{Case 8}

This 21-year-old woman presented with a $2.5-\mathrm{cm}$ laceration to her right eyebrow.

\section{Case 9}

A 19-year-old man presented with a fractured right humerus. Radiography showed extensive cystic change throughout the whole bone which was obviously longstanding and which had caused both expansion and thinning, particularly of the middle third, the crack running irregularly and extensively throughout the expanded segment of bone but without displacement. Cystic changes were also present in the neck of the scapula, suggesting this was part of a generalized bone disease.

\section{Case 10}

Case 10 was a 12-year-old girl, who presented with a fractured slipped epiphysis at the base of the proximal phalanx of her right little finger (Salter Harris Type III).

\section{Discussion}

The injuries were all different in nature and comprised the following: laceration/haematoma; dental damage; dislocated right shoulder; fractured right humerus; and fractured right little finger. But the mechanisms of injuries would appear to fall into two broad groups: first, as the riders are thrown/slip off the 'Banana' they are landed on by the rider seated behind them (i.e. a collision injury); second, injuries sustained from the equipment itself, particularly the straps on to which each rider holds (i.e. equipment injury). All the injuries were confined to the upper limb, head and face with no injuries below the chest.

The first 'Banana' arrived in Jersey about 2 years ago and currently two run from different beaches. The regulations concerning the rides are controlled by the Tourism Department and include a yearly permit, public liability insurance, pre-season equipment checks and display of an owner's risk disclaimer notice. The Tourism Department Inspectors observe the use of the 'Banana' and have authority to remove the permit or not renew it if they consider that the 'Banana' is being used irresponsibly. There is no restriction on the number of people who ride on the 'Banana'. The speedboat is controlled by the regulations laid down by the Harbour Office, which limits the towing vessel to a speed of 5 knots within 200 yards of the beach only - there is no limitation on speed when over 200 yards from the beach.

One of the people involved in the cases mentioned is currently suing the owner of the 'Banana' for injuries sustained.

\section{Appendix}

All 'Bananas' (Ocean Riders) sold by Veteka Sports are accompanied by instructions on their care and use which include the following:

NEVER tow more people than the unit is designed for.

Ensure riders wear no sharp clothing or jewellery etc.

Avoid jerking when towing, avoid slack in the tow rope, and-always tow in the direction that the Ocean Rider itself is pointing.

Use a $15-25 \mathrm{~m}$ line.

Always have an observer in the boat.

NEVER tow at speeds in excess of $15 \mathrm{~m} . \mathrm{p.h}$. (25k.p.h.).
Pay close attention to other water users.

Ensure the tow bridle at the front of the Ocean Rider is connected properly and that there are no knots etc. that might cause friction or an uneven pull, these may damage the item and cause excessive wear.

NEVER drag the Ocean Rider over sharp objects, buoys, etc.

Ensure that all riders are wearing an approved buoyancy aid.

On no account should the Boat Driver tow the Ocean Rider in a manner that deliberately causes the riders to fall off. 